\title{
Production and Characterization of the Mechanical and Thermal Properties of Expanded Polystyrene with Recycled Material'
}

\section{Producción y caracterización de las propiedades mecánicas y térmicas de poliestireno expandido con material reciclado ${ }^{2}$}

\author{
Gina Barrera Castro ${ }^{3}$ \\ Luz Ocampo Carmona \\ John Olaya Florez
}

How to cite this article:

G. Barrera Castro, L. Ocampo Carmona, and J. Olaya Florez, "Production and characterization of the mechanical and thermal properties of expanded polystyrene with recycled material," Ing. Univ., vol. 21, no. 2, pp. 177-194. http://dx.doi. org/10.11144/Javeriana.iyu21-2.mtpe

\footnotetext{
' Submitted on: March 8th, 2016. Accepted on: February 21 st 2017. Article of scientific and technological investigation. This article is part of the results of the Master's thesis in Engineering-Mechanical Engineering "Characterization of the mechanical and thermal properties of samples of EPS after consumption, used in the food industry and subjected to a recovery process", by Gina Paola Barrera Castro.

${ }^{2}$ Fecha de recepción: 8 de marzo de 2016. Fecha de aceptación: 21 de febrero de 2017. Artículo de investigación científica y tecnológica. Este artículo hace parte de los resultados de la tesis de Maestría en Ingeniería-Ingeniería Mecánica "Caracterización de las propiedades mecánicas y térmicas de muestras de EPS posconsumo, utilizadas en la industria de alimentos y sometidas a un procesos de recuperación", de Gina Paola Barrera Castro.

${ }^{3}$ Degree in Technological Design, Universidad Pedagógica Nacional, Colombia. Mechanical Engineer, Fundación Universitaria Los Libertadores, Bogotá, Colombia. M.Sc., Student in Mechanical Engineering, Universidad Nacional de Colombia.

E-mail: gpbarrerac@unal.edu.co

${ }^{4}$ Chemical Engineer, Universidad de Antioquia, Medellín, Colombia. M.Sc. in Metallurgical and Materials Engineering, Universidad Federal de Rio de Janeiro, Brazil. D.sc. in Metallurgical and Materials Engineering, Universidad Federal de Rio de Janeiro. Associate professor, Universidad Nacional de Colombia, Medellín. E-mail: Imocampo@unal.edu.co.

${ }^{5}$ Metalurgical Engineer. M.Sc., Materials and Processes, Universidad Nacional de Colombia. Ph.D. in Engineering, Universidad Nacional Autónoma de México. Titular professor, Universidad Nacional de Colombia, Bogotá, Colombia.

E-mail: ijolayaf@unal.edu.co
} 


\section{Abstract}

Introduction: Three materials were made with mixtures of virgin expanded polystyrene (EPS) grade S3 and recycled material from multipurpose EPS packaging. Thee latter was subjected to washing and grinding in a blade mill, with percentages by weight of recycled material 10, 15 , and 20\%. Methodology: The mechanical properties of these materials were evaluated by testing compressive strength and flexural, impact, and thermal properties using the techniques of differential scanning calorimetry and thermogravimetry. Hot plate and steady state temperature profiles in a non-steady state were simulated with Octave 3.6.4. Results: Thee results obtained for the three mixtures showed little variation in the properties of compression, impact, glass transition, and thermal diffusivity with respect to the reference material. The regularity of the decline in mass loss as a function of temperature evidences homogeneity in the samples. $\square \mathrm{e}$ flexural strength decreased the maximum failure load compared to the virgin material, and the thermal conductivity exceeded $0.06 \mathrm{~W} / \mathrm{mK}$, reducing their insulating capacity. Conclusion: Theese materials can be industrially manufactured in order to produce packaging, caissons, and spheres, among other things.

\section{Keywords}

Expanded polystyrene, EPS recycling, EPS properties

\section{Resumen}

Introducción: En este trabajo se fabricaron tres materiales con mezclas de poliestireno expandido (EPS) virgen grado S3 y reciclado proveniente de cajas de EPS multipropósito, las últimas fueron sometidas a lavado y trituración en un molino de aspas, con porcentajes en peso de material reciclado de 10, 15 y 20\%. Metodología: Las propiedades mecánicas de estos materiales fueron evaluadas mediante los ensayos de resistencia a compresión, flexión e impacto y las propiedades térmicas mediante las técnicas de calorimetría diferencial de barrido, termogravimetría, plato caliente en régimen estacionario y se simularon los perfiles de temperaturas en régimen no estacionario a través de Octave 3.6.4. Resultados: Los resultados obtenidos en las tres mezclas fabricadas muestran poca variación de las propiedades a compresión, impacto, transición vítrea y difusividad térmica con respecto al material de referencia. La regularidad de las caídas de la pérdida de masa en función de la temperatura evidencia homogeneidad en las muestras. La resistencia a la flexión presenta disminución de la carga máxima de rotura con respecto al material virgen y la conductividad térmica presenta un aumento que supera los $0,06 \mathrm{~W} / \mathrm{mK}$, disminuyendo su capacidad aislante. Conclusiones: Los materiales fabricados pueden emplearse industrialmente para producir embalaje, casetones y esferas, entre otros.

\section{Palabras clave}

Poliestireno expandido, reciclado de EPS, propiedades EPS 


\section{Introduction}

Expanded polystyrene (EPS), derived from the addition polymerization of phenyl ethane (styrene monomer), is produced in white beads consisting of a number of closed cells, solidly supported and heat-sealed tangentially to each other, which contain still air occluded inside [1]. PS foam is produced by treating crystalline PS with a blowing agent, typically a hydrocarbon or carbon dioxide, to produce a cellular structure in the material, which reduces the brittleness, making it an excellent cushioning and insulating material [2]. Its use in food and electronics packaging, airplane and automotive parts, and sporting equipment, among other applications, has increased in the last few years due to its advantages of being light weight, easy to form, acoustic and thermally insulating, inexpensive to produce, cushioning, dimensionally stable, and heat and moisture resistant [3]-[5].

In Colombia, the expandable polystyrene manufacturing industry produces and markets long life-cycle products, such as geoblocks, cornices, insulation systems for construction and refrigerators, as well as short life-cycle products, such as multipurpose boxes and packaging systems for the transport of fragile goods and boxes, to name a few. However, short life-cycle products end their useful lives at best as solid waste that ends up in landfills and garbage dumps in different cities across the country.

The composition of solid waste in Colombia in 2010 consisted of $65 \%$ organic wastes, followed by $14 \%$ plastics [6]. Particularly in Bogota, the recycling of plastics is marginal compared to other kinds of packaging and container materials. According to CEMPRE, the amounts recovered by the collection network of the recycling company CODESARROLLO included 2932 tons of PET and 1973 tons of HDPE, LDPE, PP, and PS. The amount of plastic materials used in Colombia has increased from 169,000 tons in 2005 to 209,655 tons in 2010 , which corresponds to $27.5 \%$ of the apparent consumption of virgin plastic resins [7]. 
The increased use of polymeric materials causes their recycling to become a way to reduce environmental problems caused by polymeric waste accumulation generated from day-to-day applications of polymer materials, such as packaging and construction. The recycling of polymers waste helps to preserve natural resources, as most polymer materials are made from oil and gas [8]. Polystyrene can be recycled by mechanical, chemical, and thermal methods [9].

Most articles found in the literature on recycled expanded polystyrene use it in the concrete industry. Some of these results will be shown below.

Gu and Ozbakkaloglu [10] reported that the use of recycled plastic aggregates and fibers as construction materials has gained widespread attention in recent years. This practice can contribute significantly towards a more sustainable construction industry.

Chaukura et al. [11] concluded that current on-going research on waste polystyrene (WPS) is in development, and the evaluation of lightweight concrete, ion exchanges, and composites from WPS represents one step in that direction.

Dissanayake et al. [12] developed a novel walling system, which uses $50 \%$ recycled EPS to produce lightweight foam concrete panels. The described precast panels have a better performance than burnt clay bricks because they generate less carbon emissions and allow faster construction.

Kaya and Kar [13] used waste expanded polystyrene (EPS) in a mixture of cement and tragacanth resin to produce a new concrete material. The amount of the resin in the mixture was $0.5,1.0$, and $1.5 \%$ of the total cement, and the EPS ratios in the samples were determined as $20,40,60$, and $80 \%$ of the total volume. As the EPS and resin percentages of the samples increased, the density, thermal conductivity, compressive strength, and tensile strength decreased, and the porosity increased. The change in the physical properties shows that artificial pores (besides those of EPS) are formed in the concrete blocks, which increases the insulating characteristics of the material.

Other uses of recycled polystyrene can be found in the work of Acierno et al. [14] and Poletto et al. [15].

Acierno et al. [14] fabricated injection-molded products made from blends of virgin EPS with fractions up to $40 \%$ post-consumer recycled waste EPS under controlled conditions. The materials were characterized and a reduction in the density was found; therefore, properties such as the thermal conductivity and compressive strength are affected, although not significantly.

Poletto et al. [15] used waste EPS samples acquired from electronic goods and home appliance packaging to manufacture a thermoplastic material containing 
wood. Samples with 10, 20, 30, and 40\% wood flour with and without $2 \%$ polystyrene-maleic anhydride (SMA) and EPS flakes were processed in a co-rotating twin-screw extruder at $200 \mathrm{rpm}$. In general, the mechanical properties of the composites with and without coupling agent presented similar behavior and low density.

Nevertheless, the characterizations omitted properties such as thermal diffusivity, which is associated with the velocity of heat propagation during temperature changes over time. Thus, mixtures of virgin EPS and post-consumer recycled EPS with food residues should be examined to corroborate the effect on these properties, including materials that have not been well analyzed and using equipment that is commonly found in industrial settings in the country. In this way, possible applications can be reviewed, thus motivating the industry to work towards environmental sustainability by examining the life cycle and proving that EPS is a usable waste.

\section{Materials and methods}

\subsection{Manufacturing of the material}

The manufacture of recycled expanded polystyrene (EPS) begins with injected EPS parts (post-consumer multipurpose polystyrene boxes) that were previously washed with an industrial detergent and dried in the atmosphere for a period no less than 24 hours. The material was crushed in a blade mill or SIEMENS model Shattering 1LA3 equipped with a $5 \mathrm{~mm}$ sieve. The milling product was weighed on an industrial scale (PCE-LS) with a resolution of $0.001 \mathrm{~mm}$, according to the proportions specified in Table 1, and was powdered by a SIEMENS fan model number 2044-2 AA 1LA hopper homogenizer, as shown in Figure 1.

The properties of the milled particles in the sample residue are as follows. The bulk density of the material was $25 \mathrm{~kg} / \mathrm{m}^{3}$, calculated according to ASTM D1622-08 prior to grinding, and the EPS size after grinding was $\leq 5 \mathrm{~mm}$.

General-purpose expandable polystyrene beads (grade S3) were used in the manufacture of virgin expanded polystyrene (EPS), which were produced in Ming Dih, Taiwan, and provided by AISLAPOR (Production Plant: Canavita, Tocancipá, Colombia). This material was weighed on a scale and poured into expander 1 according to the proportions specified in Table 1. The material was pushed by a SIEMENS model 1LA3 series fan to the 106-2YB60 hopper homogenizer and finally transferred to a storage silo for at least 2 hours and up to 24 hours to prevent the loss of pentane, as explained in Figure 1. 
Figure 1. Block diagram of the operations performed with the material

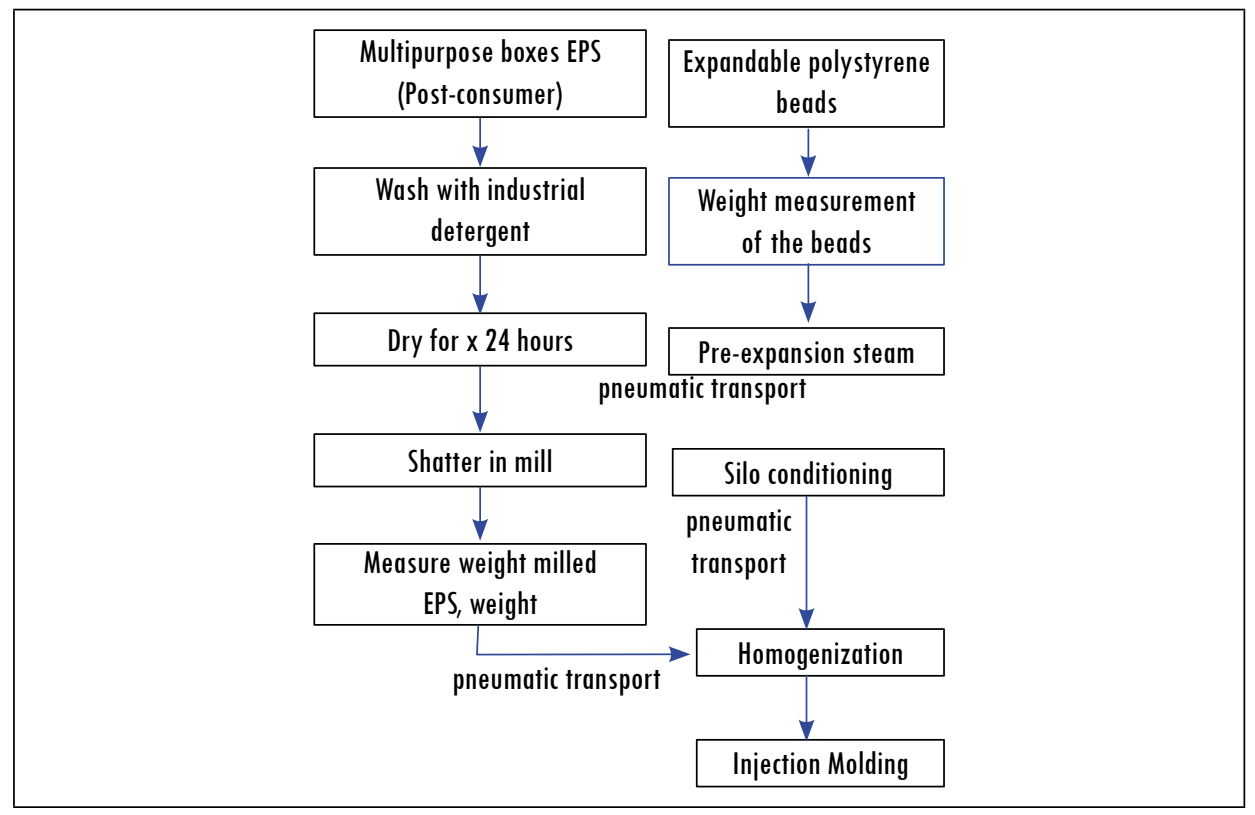

Source: Authors own elaboration.

Table 1 shows the mass in grams used in the formulations throughout the manufacturing process of the four materials and their respective identification.

Table 1. Mass in grams used in the formulations

\begin{tabular}{|l|c|c|c|c|}
\hline \multicolumn{1}{|c|}{ Samples } & \%EPS & \%EPS $_{\mathrm{r}}$ & Mass EPS $_{\mathrm{r}}(\mathrm{g})$ & Mass EPS $_{\mathrm{v}}(\mathrm{g})$ \\
\hline $\mathrm{EPS}_{0}$ & 100 & 0 & 0 & 28000 \\
\hline $\mathrm{EPS}_{10}$ & 90 & 10 & 2800 & 25200 \\
\hline $\mathrm{EPS}_{15}$ & 85 & 15 & 4200 & 23800 \\
\hline $\mathrm{EPS}_{20}$ & 80 & 20 & 5600 & 22400 \\
\hline
\end{tabular}

Source: Authors own elaboration.

Finally, the specific proportions were poured into the homogenizer to produce each of the materials. The materials were manually entered into the feed hopper of the LA-LENDLE injection machine model 90-70-20, with the operating conditions described in Table 2. 
Table 2. Injection molding conditions

\begin{tabular}{|l|l|}
\hline \multicolumn{1}{|c|}{ Conditions } & \multicolumn{1}{c|}{ Measures } \\
\hline Cylinder diameter filling tire & $120 \mathrm{~mm}$ \\
\hline Injection pressure & $1,5 \mathrm{bar}$ \\
\hline Injection rate & $45 \mathrm{~cm}^{3} / \mathrm{s}$ \\
\hline Heating power & $2,2 \mathrm{KW}$ \\
\hline Injection mold & Block $1 \mathrm{~m}^{3}$ \\
\hline
\end{tabular}

Source: Authors own elaboration.

\subsection{Infrared spectrophotometric method}

The modification degree of the manufactured materials was evaluated by analyzing the absorption bands. The spectra were obtained using a SHIMADZU model S FTIR over a wavelength range of 400 to $4000 \mathrm{~cm}^{-1}$. The samples were prepared by scraping with $\mathrm{P} 400$ CROWNMAN sandpaper. A powdered tablet was manufactured with $1 \mathrm{mg}$ of the sample in $\mathrm{KBr}$. The samples were pre-weighed on an analytical balance.

\subsection{Description of the mechanical properties}

Physical testing of the compressive resistance and bending was performed on a SHIMADZU universal testing machine model A6-1S with temperature and humidity conditions of $23 \pm 2^{\circ} \mathrm{C}$ and $50 \pm 5 \% \mathrm{RH}$, respectively.

For the compressive resistance test, the tested pieces were cut from the material produced in the injection molding machine in dimensions of $58 \times 58 \times 44$ $\mathrm{mm}( \pm 1 \mathrm{~mm})$, according to the specifications given in ASTM standards D755709 and D1621-10 ASTM 6.1. The load on the entire surface was applied at a displacement rate of $2.5 \pm 0.25 \mathrm{~mm} / \mathrm{min}$ per $25.4 \mathrm{~mm}$ of thickness, i.e., 4.3 $\mathrm{mm} / \mathrm{min}$, until the sample was compressed to approximately $13 \%$ of its original thickness or until it reached the yield point thickness.

To test the flexural resistance, the samples in sheet form were cut from the material produced in the injection molding machine in dimensions of $300 \times 75 \times 22 \mathrm{~mm}( \pm 1 \mathrm{~mm})$, according to the specifications given in paragraphs 8.2 and 8.3 of the ASTM C203-05a (2012) and ASTM D7557-09 standards, following test method I and process A, primarily designed for materials which break at relatively small deviations.

Cylindrical support edges in PVC were designed with a diameter of $33.5 \mathrm{~mm}$ and length of $100 \mathrm{~mm}$; the separation between centers was $250 \mathrm{~mm}( \pm 1 \mathrm{~mm})$. 
Specimens were bent under the flapper load and broken by the combined effects of compression and tension; in this way, the maximum breaking load was determined.

Izod impact testing was performed on unnotched samples using a Physical Test Solutions impact pendulum. Rectangular specimens cut from the material produced in the injection molding machine were used, with dimensions of $10.2 \times 63.5 \times 12.7 \mathrm{~mm}( \pm 1 \mathrm{~mm})$, according to the specifications given in Section 7 of ASTM D4812-11 and ASTM D7557-09.

\subsection{Thermal characterization}

Differential scanning calorimetry was performed using a Modulated Instruments DSC 2910, previously calibrated with an indium standard. The samples were prepared in a DuPont Instruments SN PN 900878-901 01678 hermetically encapsulating aluminum press. All measurements were performed in nitrogen atmosphere with a controlled flow of $50 \mathrm{ml} / \mathrm{min}$. Temperature sweeps were performed over the standard DSC range of 40 to $220^{\circ} \mathrm{C}$ with a sample amount of $3 \pm 0.5 \mathrm{mg}$ and a heating rate of $5^{\circ} \mathrm{C} / \mathrm{min}$. The values of the heat flow of the liquid and glassy lines, obtained through DSC, were used to extrapolate the $\mathrm{Tg}$, and the specific heat $(\mathrm{Cp})$ was calculated with Equation (1) [16].

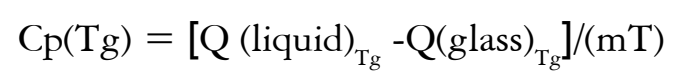

Where:

$\mathrm{Cp}=$ change in the heat capacity of the material

$\mathrm{Q}$ (liquid) ${ }_{\mathrm{Tg}}=$ heat flux in the rubber phase at the $\mathrm{Tg}$

$\mathrm{Q}$ (glass) ${ }_{\mathrm{Tg}}=$ heat flux in the glassy phase at the $\mathrm{Tg}$

$\mathrm{m}=$ total mass of the sample

$\mathrm{T}=$ temperature from the $\mathrm{Tg}$

Thermal gravimetric analysis was performed on a TA Instruments 2050 TGA, which was equipped with a platinum sample holder, previously calcined red hot to erase the thermal history. All measurements were performed in nitrogen atmosphere with a controlled flow of $50 \mathrm{ml} / \mathrm{min}$. Temperature sweeps were performed within a range of 30 to $850^{\circ} \mathrm{C}$ with a sample amount of $5 \pm 2 \mathrm{mg}$ and a heating rate of $20^{\circ} \mathrm{C} / \mathrm{min}$.

The thermal conductivity was measured on hot plate equipment that consisted of thermocouples with 12 measurement points, a k-type display, a digital multimeter, a digital ammeter, a gauge, measuring tape, and a variable voltage 
source. In total, 2 cuttings for each of the tested materials were used as samples. The cuttings had dimensions of $300 \times 300 \times 24( \pm 1 \mathrm{~mm})$ and were taken from the material produced in the injection molding machine, according to the specifications given by ASTM C177-10 and considering the direction of compression molding.

For the test, two plates were mounted on the sample stage on the test bench. The equipment was hermetically sealed, and the average exposure temperature was kept under the glass transition temperature obtained from the DSC experiment to prevent softening of the material in each case. The material was exposed in the equipment until it reached a steady state. The thermal diffusivity was determined in this state according to Equation (2) [17].

$$
\alpha=\frac{k}{\rho C_{p}}
$$

Where:

$\alpha=$ thermal diffusivity

$k=$ thermal conductivity

$C_{p}=$ specific heat

$\rho=$ density of the material

The heat transfer differential equation can be solved by the finite difference in one dimension for the case of a flat wall, resulting in Equation (3). This equation was used to write the code for the Octave 3.6.4 software and to simulate the temperature distribution profile in the non-stationary regime for the reference material and the manufactured EPS ${ }_{10}, \mathrm{EPS}_{15}$, and EPS . $_{20}$

$T_{i}^{k+1}=T($ node $)(1-2 * r)+r * T($ node +1$)+r * T($ node -1$)$

Where:

$i \quad=$ node number

$k \quad=$ time interval

$T=$ temperature

node $=$ subdivision of the distance between the measurement of one $\mathrm{T}$ and another $\mathrm{T}$ 


$$
r=\frac{\alpha \Delta T}{n o d e^{2}}
$$

\section{Results}

\subsection{Infrared spectroscopy test}

Characteristic bands include the absorption bands at 3088, 3059, and 3030 $\mathrm{cm}^{-1}$, corresponding to "stretching" vibrations of the aromatic $\mathrm{C}-\mathrm{H}$ bonds. The absorption bands at 2921 and $2848 \mathrm{~cm}^{-1}$ are due to symmetric and asymmetric vibration, respectively, and $\mathrm{C}-\mathrm{H}$ "stretching" of $\mathrm{CH}_{2}$ in the polystyrene backbone. An absorption band corresponding to the "stretching" of the $\mathrm{C}-\mathrm{C}$ bond in the ring plane appears at $1503 \mathrm{~cm}^{-1}$. "Stretching" vibrations of the $\mathrm{C}-\mathrm{H}$ ring are observed at 1445 and $1366 \mathrm{~cm}^{-1}$, and in-plane "bending" bands of the $\mathrm{C}-\mathrm{H}$ ring are observed at $1176,1140,1067$, and $1030 \mathrm{~cm}^{-1}$. Finally, the characteristic out-of-plane "bending" vibrational bands of $\mathrm{C}-\mathrm{H}$ in the aromatic ring appear at $900,841,754,689$, and $529 \mathrm{~cm}^{-1}$, as shown in Figure 2.

Figure 2. Infrared spectra of the polystyrene powder samples: (a) $\operatorname{EPS}_{0^{\prime}}$ (b) EPS ${ }_{10^{\prime}}$ (c) PPS $_{15^{\prime}}$ and (d) EPS

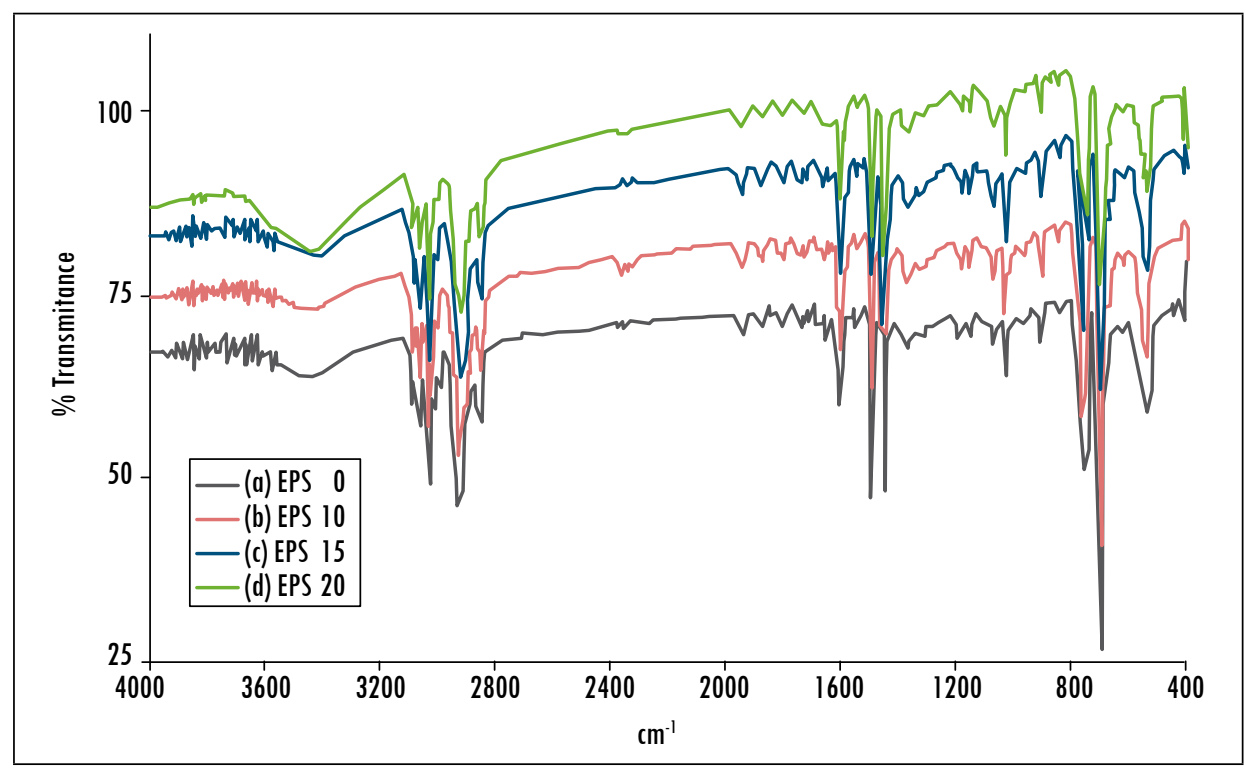

Source: Authors own elaboration. 


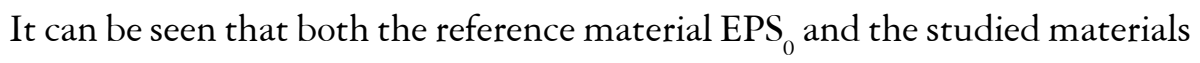
EPS $_{10}$, EPS $_{15}$, and EPS 20 correspond to the same polymer, with no evidence of oxygenated groups composed of environmental agents or any other functional group formed during degradative processes such as washing and milling of the recycled material.

\subsection{Mechanical properties}

Table 3 shows the results of the determination of the mechanical properties of the materials produced in comparison to the $\mathrm{EPS}_{0}$ reference material. The three EPS mixtures exhibit a low compressive load, which is very similar to the behavior of the EPS 0 reference material. The deflection observed during the test was homogeneous, and resistance to this kind of force remained constant at $0.11 \mathrm{MPa}$, with little significant variation among the materials studied.

Table 3. Mechanical properties of EPSv and mixtures of EPSv and EPSr

\begin{tabular}{|l|c|c|c|c|}
\hline \multicolumn{1}{|c|}{ Samples } & EPS $_{0}$ & EPS $_{10}$ & EPS $_{15}$ & EPS $_{20}$ \\
\hline Properties & $0.11 \pm 0.00$ & $0.11 \pm 0.00$ & $0.11 \pm 0.00$ & $0.11 \pm 0.00$ \\
\hline Compressive resistance (MPa) & $2.86 \pm 0.10$ & $3.38 \pm 0.96$ & $4.24 \pm 0.64$ & $3.62 \pm 0.92$ \\
\hline Modulus of elasticity (MPa) & $68.4 \pm 5.64$ & $46.5 \pm 4.32$ & $53 \pm 5.17$ & $52.1 \pm 3.28$ \\
\hline Maximum breaking load (N) & $23.1 \pm 3.35$ & $23.1 \pm 0.41$ & $24 \pm 7.41$ & $22 \pm 3.31$ \\
\hline Maximum displacement (mm) & $0.5 \pm 0.05$ & $0.3 \pm 0.05$ & $0.4 \pm 0.05$ & $0.4 \pm 0.05$ \\
\hline Maximum stress (N/mm $\left.{ }^{2}\right)$ & $5.5 \pm 0.81$ & $5.7 \pm 0.82$ & $5.8 \pm 1.78$ & $5.3 \pm 0.79$ \\
\hline Maximum deformation $(\%)$ & $0.06 \pm 0.00$ & $0.06 \pm 0.01$ & $0.05 \pm 0.00$ & $0.06 \pm 0.00$ \\
\hline Energy absorbed in the impact $(\mathrm{J})$ & $5.43 \pm 0.21$ & $6.03 \pm 0.95$ & $5.43 \pm 0.21$ & $6.18 \pm 0.39$ \\
\hline Impact resistance $(\mathrm{J} / \mathrm{m})$ & & & &
\end{tabular}

Source: Authors own elaboration.

However, when comparing the modulus of elasticity of EPS ${ }_{0}$, corresponding to $2.86 \mathrm{MPa}$, with the results for $\mathrm{EPS}_{10}, \mathrm{EPS}_{15}$, and $\mathrm{EPS}_{20}$, an increasing linear trend can be observed, and in turn, a greater spread in the data appear. This indicates that the increase in the percentage of recycled material makes the mixture more rigid [18]. Given that the modulus is closely related to the binding energy of the linked molecules, it is possible that the electrostatic attraction tends to be slightly reduced, causing a loss in the flexibility of the polymer chain [19] and affecting other mechanical properties. When the cells in EPS are destroyed, they 
probably release air/n-pentane gas and in turn lose cohesiveness, and therefore, the material depends on pristine pearls to stay together.

The impact resistance ranges between 5.43 and $6.18 \mathrm{~J} / \mathrm{m}$, with no significant variation in the ability of the material to withstand collisions when increasing the percentage of recycled material, and the energy absorption observed during impact is maintained at approximately $0.06 \mathrm{~J}$. This property also applies to $\mathrm{EPS}_{0}$, and the fault presented in the 4 materials under study is complete fracture; that is, the sample separated into two parts. Therefore, the rigid component in the structure of the manufactured materials is still low and, thus, does not affect the mechanical properties. These results explain the absence of significant effects for EPS $_{v}$ and EPS mixtures, causing the formation of intermediate phases or structures that affect the characteristics of the initial components [20].

By contrast, the bending test showed a decrease in the maximum tensile resistance with respect to that of the EPS reference material. The value of EPS $_{10}$ was approximately $68 \%, \mathrm{EPS}_{15} 77 \%$, and $\mathrm{EPS}_{20} 76 \%$, considering the maximum load to break was $68.4 \mathrm{~N}$, corresponding to an $\mathrm{EPS}_{0}$ value of $100 \%$. Thus, brittleness is exhibited by the manufactured material, although EPS 0 breaks when elastically deformed. However, in the materials produced, the highest tensile resistance is significantly lower than that of the reference material; that is, elastic deformation occurs faster. It is evident that upon subjecting the EPS to grinding, a reduction in the average length of the PS chains and the molecular weight results [18], [19].

The presence of recycled material transforms $\mathrm{EPS}_{10}, \mathrm{EPS}_{15}$, and EPS 20 into a stiffer, more brittle material, depending on the proportion of recycled material, though all three materials show a very similar decrease.

Given that the assay combines bending compression stress and tensile resistance, it follows that by applying tensile forces to EPS ${ }_{10}$ EPS $_{15}$, and EPS 20 , the bonds between the molecular chains are more quickly overcome with respect to $\mathrm{EPS}_{0}$, which in the case of amorphous thermoplastics, occurs through van der Waals forces.

The mechanical characteristics of the manufactured materials EPS ${ }_{10}, \mathrm{EPS}_{15}$, and EPS $_{20}$ define them as foamed polymers with good resilience when subjected to compression and impact resistance and poor when subjected to bending stresses. This establishes that the long chain structure is preserved, which provides resistance, as well as toughness, except when the material is subjected to bending or pulling. 


\subsection{Thermal properties}

Table 4 shows the results of the temperature scan from $40^{\circ} \mathrm{C}$ to $220^{\circ} \mathrm{C}$, where a single glass transition temperature $(\mathrm{Tg})$ is observed in all materials produced. It is possible to characterize the structure of the materials produced as an amorphous solid state, in accordance with the EPS $_{0}$ reference material.

Table 4. Thermal properties of EPS and mixtures of EPS and EPS,

\begin{tabular}{|l|c|c|c|c|}
\hline \multicolumn{1}{|c|}{ Samples } & EPS $_{0}$ & EPS $_{10}$ & EPS $_{15}$ & EPS $_{20}$ \\
\hline Properties & 101.4 & 96.5 & 97.1 & 104.5 \\
\hline Glass transition temperature $\left({ }^{\circ} \mathrm{C}\right)$ & 0.5 & 0.5 & 0.6 & 0.9 \\
\hline Specific heat $C_{p}(\mathrm{KJ} / \mathrm{Kg} . \mathrm{K})$ & 326.7 & 300.2 & 318.6 & 313.6 \\
\hline $\begin{array}{l}\text { Onset temperatue of material } \\
\text { degradation }\left({ }^{\circ} \mathrm{C}\right)\end{array}$ & 0.059 & 0.070 & 0.062 & 0.056 \\
\hline Thermal conductivity $k(\mathrm{~W} / \mathrm{mK})$ & 23 & 22 & 23 & 22 \\
\hline Density $\rho\left(\mathrm{kg} / \mathrm{m}^{3}\right)$ & $4,9 \times 10^{-9}$ & $6,4 \times 10^{-9}$ & $4,3 \times 10^{-9}$ & $2,8 \times 10^{-9}$ \\
\hline Thermal diffusivity $\alpha\left(\mathrm{m}^{2} / \mathrm{s}\right)$ & & &
\end{tabular}

Source: Authors own elaboration.

Softening of the EPS ${ }_{10}$ material can be observed at $96.5^{\circ} \mathrm{C}$, with a difference of $-4.9^{\circ} \mathrm{C}$ with respect to $\mathrm{EPS}_{0}$. In the case of $\mathrm{EPS}_{15}, 97.1^{\circ} \mathrm{C}$ is obtained with a difference of $-4.3^{\circ} \mathrm{C}$ compared to $\mathrm{EPS}_{0}$, and for $\mathrm{EPS}_{20}$, molecular motion occurs at $104.5^{\circ} \mathrm{C}$ with a difference of $3.1^{\circ} \mathrm{C}$ relative to EPS. It can be seen that the glass transition temperature shows no significant difference between the materials under study, but there is a small decrease in the value obtained for the blends compared to the reference material $\left(\mathrm{EPS}_{0}\right)$, except for $\mathrm{EPS}_{20}$, which may possibly be an experimental error.

This effect can be explained by the loss of pentane emitted into the atmosphere throughout the life cycle of the product and during the destruction of the EPS $_{\mathrm{r}}$ pearl when subjected to grinding. This is in agreement with the decrease in the observed maximum load break when subjected to bending and the increased elastic modulus and mixtures of EPS ${ }_{\mathrm{r}}$ and EPS ${ }_{\mathrm{V}}$. Additionally, the onset degradation temperatures of the materials determined via TGA are presented.

The thermogravimetric analysis of $\mathrm{EPS}_{0}$ gave an onset degradation temperature of $326.7^{\circ} \mathrm{C}$. In the case of EPS ${ }_{10}$, this effect was seen at $300.2^{\circ} \mathrm{C}$. In EPS $_{15}$, a temperature of $318^{\circ} \mathrm{C}$ was obtained, and for $\mathrm{EPS}_{20}$, degradation was observed at $313.6^{\circ} \mathrm{C}$. 
In this test, the onset degradation temperature of the manufactured materials containing a percentage of EPS $_{\mathrm{r}}$ decreased with respect to the reference material. The thermograms shown in Figure 3demonstrate the homogeneity in the formulations, since there is clear uniformity and regularity in the decrease in mass loss versus temperature. There is no evidence of intermediate structures significantly affecting the characteristics of the initial components.

Figure 3. Thermal gravimetric analysis of (a) EPS (b) $^{\prime}$ (bPS I0 $^{\prime}$ (c) EPS $_{15^{\prime}}$ and (d) EPS 20

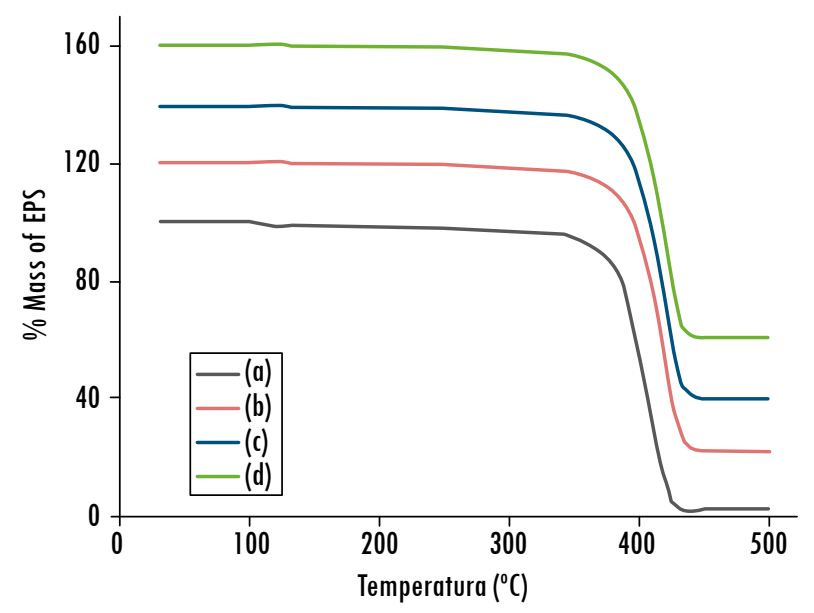

Source: Authors own elaboration.

The hot plate test determined the thermal conductivity $(k)$ of EPS $_{0}$ to be $0.059 \mathrm{~W} / \mathrm{mK}$. When compared to this reference, the results of the mixtures present the following variations: for $\mathrm{EPS}_{10}, k=0.070 \mathrm{~W} / \mathrm{mK}$, with a variation of 0.011 corresponding to an $18 \%$ difference; for $\mathrm{EPS}_{15}, k=0.062 \mathrm{~W} / \mathrm{mK}$, with a variation of 0.003 corresponding to a $5.1 \%$ difference; and for EPS $_{20}$, $k=0.056 \mathrm{~W} / \mathrm{mK}$, with a variation of -0.003 corresponding to a $5.1 \%$ difference.

The difference in the values may be due to the sections of material employed as samples in each case and the random distribution of the recycled material in the studied plate, since the homogenization in the production process, although acceptable, is far from ideal. However, the results obtained make it possible to state that the overall thermal conductivity values increase with respect to the reference material, exceeding the permitted value for thermal insulating materials and poor conductors of $0.06 \mathrm{~W} / \mathrm{mK}$.

This behavior can be explained as follows: the three materials, with varying proportions of recycled material, may have a more solid cellular structure and, 
in turn, decreased content of air cells. This allowed an increase in vibrational energy transport and the translation and rotation of molecules resulting from collisions with phonons from the high temperature regions to the low temperature regions, which permitted a greater flow of heat transfer. However, the contribution of thermal electron conduction, that is, conduction by free electrons, can be discarded because the variation is not significant compared to that of good conductors [20].

These results were determined at a temperature approximately $30 \%$ below the glass transition temperature, thus preventing softening of the materials studied.

All data obtained from the thermal diffusivity measurements were determined on the order of $10^{-9} \mathrm{~m}^{2} / \mathrm{s}$; that is to say, as for the reference material, $\mathrm{EPS}_{10}, \mathrm{EPS}_{15}$, and EPS can be characterized as poor diffusers, since the rate of heat propagation during temperature changes is very low, as shown in Figure 4, as determined by the simulations in Octave over $2500 \mathrm{~min}$ by means of the one-dimensional temperature distribution profiles in the four formulations, showing very similar results.

Figure 4. Linear distribution of temperatures in a plate with a thickness of $0.50 \mathrm{~m}$ in the unsteady state with inhomogeneous boundary conditions $\left(T[0,0]=0^{\circ} \mathrm{C}\right.$ and $\mathrm{T}\left[0,0.5=80^{\circ} \mathrm{C}\right)$ and a time interval of 500, i.e., 2500 minutes: (a) EPS with $\alpha=4.9 \times 10^{-9} \mathrm{~m}^{2} / \mathrm{s}$, (b) EPS Ev $_{10}$ with $\alpha=6.2 \times 10$ ${ }^{9} \mathrm{~m}^{2} / \mathrm{s}$, (c) EPS Es $_{15}$ with $\alpha=4.3 \times 10^{-9} \mathrm{~m}^{2} / \mathrm{s}$, and (d) EPS ${ }_{20}$ with $\alpha=2.8 \times 10^{-9} \mathrm{~m}^{2} / \mathrm{s}$

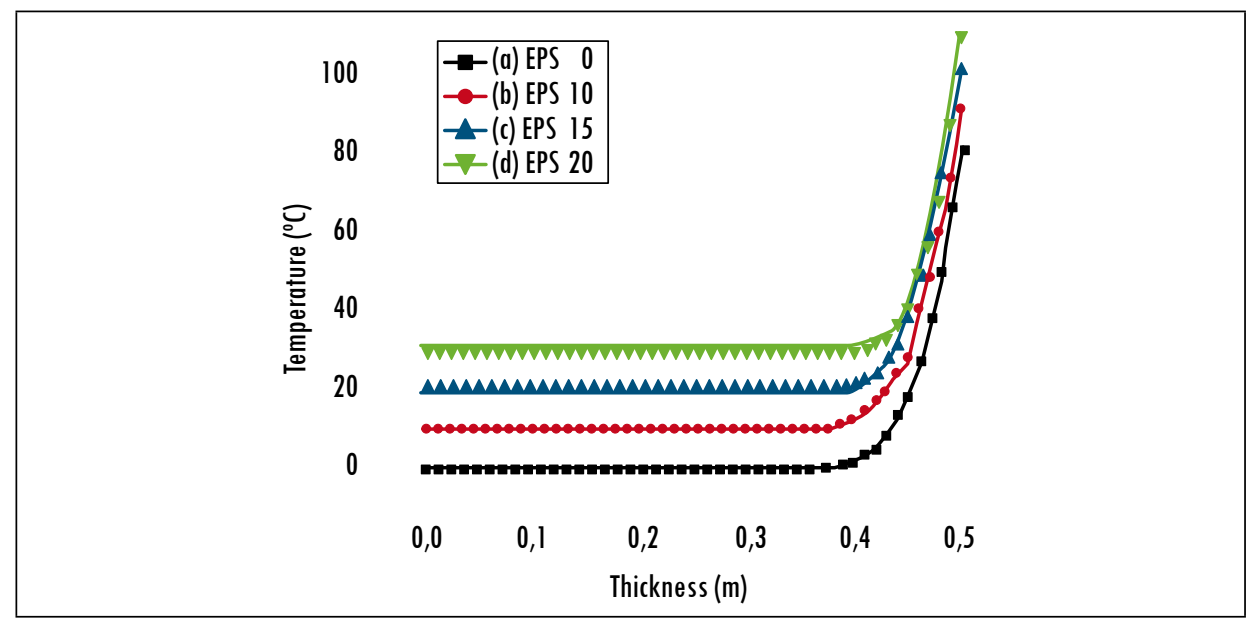

Source: Authors own elaboration.

In the last measured time interval shown in the graph, at a distance of 0.4 $\mathrm{m}$ of its thickness, $\mathrm{EPS}_{0}$ exhibits $\mathrm{T}=1.6^{\circ} \mathrm{C}, \mathrm{EPS}_{10}$ exhibits $\mathrm{T}=2.8^{\circ} \mathrm{C}, \mathrm{EPS}_{15}$ 
exhibits $\mathrm{T}=1.3^{\circ} \mathrm{C}$, and $\mathrm{EPS}_{20}$ exhibits $\mathrm{T}=0.5^{\circ} \mathrm{C}$, showing in all cases a very low warming rate without exceeding the rate of heat propagation in the reference material, except for EPS $_{10}$, since this material exceeded the thermal conductivity of EPS ${ }_{0}$ and maintained its specific heat. However, the difference does not exceed $2^{\circ} \mathrm{C}$ after 2500 minutes, i.e., heat propagation continues to be slow.

\section{Conclusions}

Materials consisting of EPS ${ }_{\mathrm{v}}$ and EPS mixtures containing recycled material from food industry wastes in weight percentages of 10,15 , and 20, were produced using a secondary reprocessing method. These materials could have a positive impact on the industry, since the amount of EPS required for the development of some products is reduced, and the overall life cycle of the EPS products is increased.

The mechanical properties of the manufactured materials EPS ${ }_{10}, \mathrm{EPS}_{15}$ and EPS $_{20}$ defines them as foamed polymers with good strength when subjected to compression and impact stress and poor strength when subjected to bending stresses. This establishes that the long-chain structure provides resistance, except when the material is subjected to flexural or tensile stresses, where the branches possibly supply tenacity.

The thermal properties show no significant difference between the materials under study; therefore, the current thermoforming processes are compatible with the $\mathrm{EPS}_{10}, \mathrm{EPS}_{15}$, and $\mathrm{EPS}_{20}$ materials.

A significant contribution of this research is the measurement of the thermal diffusivity. In all cases, the data were on the order of $10^{-9} \mathrm{~m}^{2} / \mathrm{s}$; that is to say, as for the reference material, EPS ${ }_{10}, \mathrm{EPS}_{15}$, and $\mathrm{EPS}_{20}$ can be characterized as poor diffusers, since the rate of heat propagation during temperature changes is very low. Thus, it was possible to study one of the main properties that characterize expanded polystyrene. However, due to the limited access to equipment that can perform this measurement, it is recommended to carry out studies where these results can be verified and used for new industrial applications.

\section{References}

[1] I. Tsivintzelis, A. G. Angelopoulou, and C. Panayiotou, "Foaming of polymers with supercritical $\mathrm{CO}_{2}$ : An experimental and theoretical study", Polymer, vol. 48, pp. 5928-5939, 2007. [Online]. doi: http://doi:10.1016/j.polymer.2007.08.004

[2] C. Arriaga, C. Adrián, J. López, M. Hernández, R. Echavarría, and V. Ovando, "Thermal characterization of microwave assisted foaming of expandable polystyrene". Ingeniería 
Investigación y Tecnología, vol. XVII, no. 1, pp. 15-21, Jan.-Mar. 2016. [Online]. doi: http://dx.doi.org/10.1016/j.riit.2016.01.002

[3] EPS, Industry Alliance Packaging, "Expanded polystyrene packaging environmental profile analysis”, 2009. [Online]. Available: http://www.epspackaging.org/images/stories/ EPS_Environmental_Profile_Analysis- lores.pdf.

[4] A. Emblem and H. Emblem, Eds., "Plastics properties for packaging materials," in Packaging Technology Fundamentals, Materials and Processes. Philadelphia: Woodhead Publishing Limited, 2012.

[5] E. Susan, M. Selke, and J. Culter, "Foams, cushioning, and distribution packaging," in Plastics Packaging Properties, Processing, Applications, and Regulations, $3^{\text {rd }}$ ed. Cincinnati: Hanser Publications, 2016, pp. 340-341.

[6] G. Pernett, "Eco-materiales: la incidencia negativa de la construcción en el medio ambiente," Revista de Investigación Universidad América, vol. 4, no. 1, pp. 61-77, 2011.

[7] Compromiso Empresarial para el Reciclaje (CEMPRE), "Estudio Nacional de Reciclaje", 2011, Abril. [Online]. Available: http://www.cempre.org.co/sites/default/files/3926estudio_nacional_de_reciclaje_aproximación_al_mercado_de_reciclables_y_las_experiencias_significativas_0.pdf

[8] K. Hamad, M. Kaseem, and F. Deri, "Recycling of waste from polymer materials: An overview of the recent Works.” Polymer Degradation and Stability, vol. 98, no. 2, pp. 28012812, 2013. [Online]. doi: http://dx.doi.org/10.1016/j.polymdegradstab.2013.09.025

[9] T. Maharana T, Y. Negi, and B. Mohanty, "Recycling of polystyrene," Polymer-Plastics Technology and Engineering, vol. 46, no. 7, pp. 729-736, March 2007.

[10] L. Gu and T. Ozbakkaloglu, "Use of recycled plastics in concrete: A critical review," Waste Management, vol. 51, pp. 19-42, 2016. [Online]. doi: http://dx.doi.org/10.1016/j. wasman.2016.03.005

[11] N. Chaukura, W. Gwenzi, T. Bunhu, Deborah T. Ruziwa, and I. Pumure, "Potential uses and value-added products derived from waste polystyrene in developing countries: A review," Resources, Conservation and Recycling, no. 107, 157-165, 2016. [Online]. doi: http://dx.doi.org/10.1016/j.resconrec.2015.10.031

[12] D. Dissanayake, C. Jayasinghe, and M. J Jayasinghe, "A comparative embodied energy analysis of a house with recycled expanded polystyrene (EPS) based foam concrete wall panels," Energy and Buildings, vol. 135, pp. 85-94, Nov. 2016. [Online]. doi: https://doi. org/10.1016/j.enbuild.2016.11.044

[13] A. Kaya and F. Kar, "Properties of concrete containing waste expanded polystyrene and natural resin," Construction and Building Materials, vol. 105, pp. 572-578, Feb. 2016. [Online]. doi: http://dx.doi.org/10.1016/j.conbuildmat.2015.12.177 
[14] S. Acierno, C. Carotenuto C., and M. Pecce, "Compressive and thermal properties of recycled EPS foams," Polymer-Plastics Technology and Engineering, vol. 49, no. 1, pp. 13-19, Dec. 2010. [Online]. doi: http://dx.doi.org/10.1080/03602550903282994

[15] M. Poletto, H. Ornaghi, and A. Zattera, "Characterization of composites based on expanded polystyrene wastes and wood flour," Waste Management, vol. 31, no. 4, pp. 779-784, Apr. 2011. [Online]. doi: http://dx.doi.org/10.1016/j.wasman.2010.10.027

[16] J. Mano, "Propiedades térmicas de los polímeros en la enseñanza de la ciencia de materiales e ingeniería. Estudios DSC sobre Poli (Tereftalato de Etileno)," Journal of Materials Education, vol. 25, nos. 4-6, pp. 161-164, 2003. [Online]. Available: http://www.redalyc. org/pdf/266/26625607.pdf

[17] A. Salazar, "On thermal diffusivity," Eur. J. Phys, no. 24, pp. 351-358, 2003. [Online]. Available: http://iopscience.iop.org/article/10.1088/0143-0807/24/4/353/pdf

[18] J. Perilla, L. Chaparro, C. Escorcia, and N. López, "Mezcla de materiales poliméricos I. Evaluación de las mezclas de poliestireno virgen y reciclado," Revista Ingeniería e Investigación, vol. 44, pp. 80-83, 1999. [Online]. Available: http://revistas.unal.edu.co/index. php/ingeinv/article/view/21303

[19] A. López, "Influencia del proceso de reciclado sobre las propiedades de los materiales compuestos obtenidos por inyección de poliestireno reforzado con fibras lignocelulósicas", D.S. Thesis, Universidad de Girona, Girona, España, 2004. [Online]. Available: http:// www.tdx.cat/handle/10803/7759

[20] W. Callister, Introducción a la ciencia e ingeniería de los materiales 2. Madrid: Reverté, 2007. 